\title{
Review
}

\section{Molecular biology of Type 1 (insulin-dependent) diabetes mellitus*}

\author{
A. Lernmark \\ Hagedorn Research Laboratory, Gentofte, Denmark
}

Diabetes mellitus has been known to man since ancient times. There are many documents available or quoted throughout several centuries and, closer to our times, accounts of experiments to explain the origin of diabetes mellitus. In the classical series of experiments in dogs involving pancreatectomies, von Mering and Minkowski [1] in 1889 concluded that complete removal of the pancreas caused diabetes. It was not a transient glycosuria but a true, lasting diabetes mellitus which, in every respect, mimicked the worst type of this disease found in man. In a second study, Minkowski [2] reported on a larger number of dogs in which pancreatectomy was performed, further emphasizing the striking disorders in glucose metabolism which are associated with removal of the pancreas. It was concluded that diabetes mellitus was associated with an hitherto unknown function of the pancreas. The possible relationship to the islets of Langerhans did not become evident until several years later. In fact, although pathologists in the early years of this century reported morphological alterations in the islets of Langerhans of patients with diabetes, it was not until 1965 that Gepts [3] by careful morphological investigations showed major abnormalities in a number of $\beta$ cells and the presence of inflammatory cells in the islets of Langerhans in newly diagnosed Type 1 (insulin-dependent) diabetic patients. Recent studies with morphometric techniques [4-5], which allow a quantitative measure of both the total volume or mass of the endocrine pancreas of individual cell types visualized by sensitive and specific immunocytochemical techniques, have shown that Type 1 diabetes in man is associated with a specific loss of the pancreatic $\beta$ cells (Fig.1). The disappearance of $\beta$ cells is linked to a diminished mass of the endocrine pancreas, but the total mass of A (glucagon), D (somatostatin) and pancreatic polypeptide cells seemed to remain within the normal range [4]. Type 1 diabetes seems, therefore, to represent nature's own $\beta$-cytectomy, a procedure yet impossible to carry out in specific experiments. Chemical agents, such as alloxan and streptozotocin, are $\beta$-cytotoxic but their effects are harmful to other cells also.

* This Review is based on the 19th Minkowski Lecture presented at the EASD meeting, September 1984
What are the molecular mechanisms which govern the extermination of $\beta$ cells? Numerous investigations, parcularly during the last 25 years have suggested that $\beta$ cells are lost in association with a specific autoimmune reaction (Table 1). It is possible that a precise and concerted activity of the immune system might be directed against certain molecules which amongst the endocrine islet cells occur only on the $\beta$ cell (Fig. 2). The particular features of this cell is its ability to synthesize, store and release insulin. The biosynthetic pathway of insulin is well described [21]. However, the critical components which are involved in the control of $\beta$-cell function, i.e. recognition of $D$-glucose as a major stimulus for insulin release, initiation of secretion and glucose control of insulin biosynthesis, are yet to be identified. One hypothesis to explain the specific loss of the pancreatic $\beta$ cells in Type 1 diabetes is that an abnormal immune reaction, being controlled by certain HLA-D region genes, is directed explicitly against molecules expressed solely on the $\beta$ cell. Recent advances in biology and medicine,

(A)

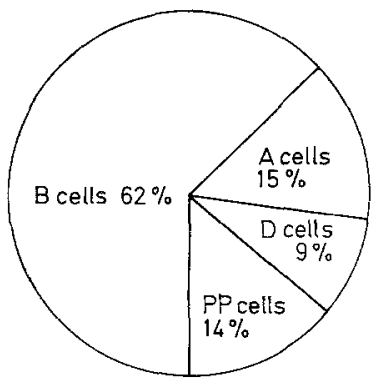

CONTROL: pancreatic mass $1395 \mathrm{mg}$

(B)

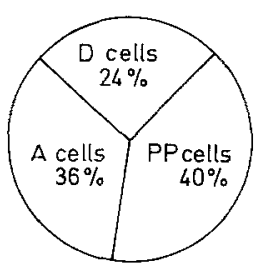

TYPE I DIABETES: pancreatic mass $413 \mathrm{mg}$

Fig. $1 \mathrm{~A}$ and $\mathbf{B}$. The endocrine pancreatic mass in $\mathbf{A}$ healthy control subjects and $\mathbf{B}$ Type 1 (insulin-dependent) diabetic patients and the relative distribution of the endocrine $\mathrm{B}, \mathrm{A}, \mathrm{D}$ and pancreatic polypeptide (PP) cells (Data from 4) 
Table 1. Immune phenomena associated with Type 1 diabetes

\begin{tabular}{|c|c|}
\hline Immune phenomena & Reference \\
\hline $\begin{array}{l}\text { Cellular immune abnormalities } \\
\text { Insulitis }\end{array}$ & Gepts [3] \\
\hline $\begin{array}{l}\text { Cellular hypersensitivity } \\
\text { to pancreatic antigens }\end{array}$ & Nerup et al. [6] \\
\hline $\begin{array}{l}\text { Some alterations } \\
\text { in } \mathrm{T} \text { - and B-lymphocytes }\end{array}$ & $\begin{array}{l}\text { Mascart-Lemone et al. [7] } \\
\text { Jackson et al. [8] }\end{array}$ \\
\hline Signs of polyclonal activation & $\begin{array}{l}\text { Horita et al. }[9] \\
\text { Papadopoulos et al. }[10]\end{array}$ \\
\hline $\begin{array}{l}\text { Humoral immune abnormalities } \\
\text { Autoantibodies reactive } \\
\text { with islet cells }\end{array}$ & $\begin{array}{l}\text { Bottazzo et al. [11] } \\
\text { MacCuish et al. [12] } \\
\text { Lernmark et al. [13] } \\
\text { Doberson et al. [14] } \\
\text { Bækkeskov et al. [15] }\end{array}$ \\
\hline Other organ-specific autoantibodies & $\begin{array}{l}\text { Nerup and Binder [16] } \\
\text { MacCuish and Irvine [17] }\end{array}$ \\
\hline \multirow{2}{*}{$\begin{array}{l}\text { Genes linked to HLA-region Class II } \\
\text { antigens important in controlling the } \\
\text { immune response }\end{array}$} & $\begin{array}{l}\text { Platz et al. [18] } \\
\text { Cudworth and Wolf [19] }\end{array}$ \\
\hline & Owerbach et al. [20] \\
\hline
\end{tabular}

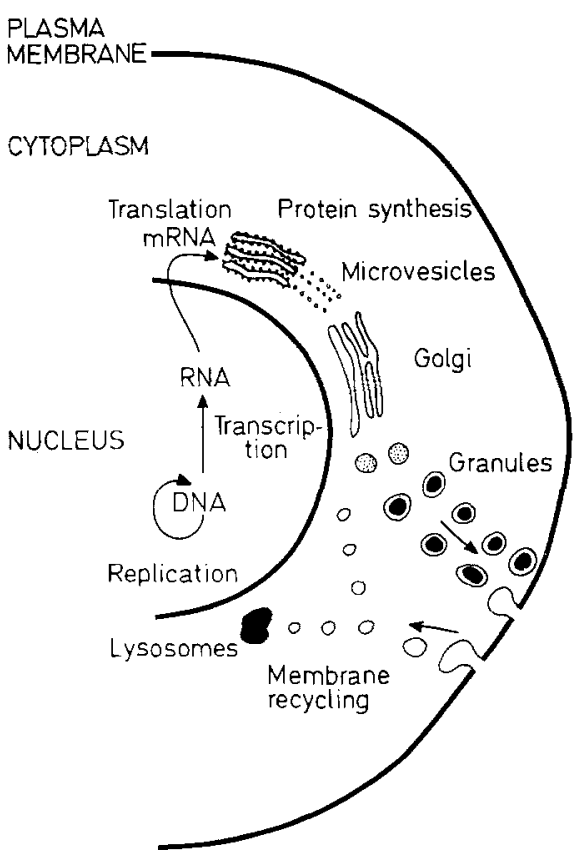

Fig. 2. Schematic diagram of a pancreatic $\beta$ cell showing the major pathways and cellular localisation of gene activities, protein synthesis and formation of organelles involved in storage and secretion of insulin

most prominently the rapid development of molecular biology, now offer new and powerful means by which to study these aspects of Type 1 diabetes mellitus.

\section{Effects of islet cell antibodies}

The immune system is able to generate innumerable variants of immunglobulin molecules that can bind to their corresponding antigen or to part of the antigen.
The variable region of immunoglobulin heavy and light chains is coded for by several genes, present in germline DNA, which, following antigen-specific stimulation, are re-arranged somatically to form the variable region gene. The expression of immunoglobulin genes and the resulting secreted form of antibody molecules are also highly diverse. There are differences in binding capacity to one and the same antigen and the ability to mediate innate immune functions, such as complementdependent cytotoxicity, may vary. The tissue preparation which harbours the antigen and the method used to detect the antibody-antigen complex is therefore of importance in the detection and characterization of an antibody. During the last few years, a number of assay systems have been developed to permit the detection of islet cell antibodies associated with the onset of Type 1 diabetes (Table 2).

Islet cell cytoplasmic antibodies (ICA) are detected by an indirect immunofluorescence test on frozen sections of human pancreas [11, 12, 22, 23]. The ICA reaction usually covers all endocrine islet cells, but it is possible, with a specific monoclonal antibody to human proinsulin [27] to demonstrate that the reaction clearly involves $\beta$ cells [28]. The antigen(s) detected by ICA remain to be identified. It has been much debated whether ICA are involved in the pathogenesis of Type 1 diabetes or whether they appear after lesions to the $\beta$ cells. The reaction pattern of ICA towards intracellular molecules is often used as an argument that these antibodies represent a secondary response to an unknown primary lesion. It is conceivable that damage inflicted to $\beta$ cells and resulting in a specific lysis, could release intracellular antigens that would be recognized by the immune system thus leading to the formation of ICA. In this respect, ICA would represent a marker for $\beta$-cell destruction, on-going or already passed. If ICA levels are regulated as immunoglobulins in general, one would assume that the ICA levels decrease with decreasing levels of antigen. It was, therefore, of considerable interest that early cross-sectional studies showed a decreased prevalence of ICA with increasing duration of Type 1 diabetes $[12,23]$. However, it was not clear from these studies to what extent the decrease reflected varying levels of ICA. Thus, efforts were made to standardize the ICA assay, to control its reproducibility and to estimate endpoint titres [29]. This approach was used to follow 82 newly diagnosed Type 1 diabetic patients, with an age of onset representative of the age-related incidence of Type 1 diabetes in Denmark [30]. The end-point titre of ICA was determined on nine occasions during a 30-month follow-up period, together with fasting Cpeptide levels as a measure of residual $\beta$-cell function. The median fasting C-peptide level was below the lower limit of normal at diagnosis, but rose rapidly, yet temporarily, for 1-6 months following initiation of insulin therapy. However, after 1 year, fasting C-peptide levels decreased continuously, reaching a median level below the lower limit of normal control subjects 30 months after commencing insulin therapy. The decrease in fasting 
Table 2. Islet cell antibodies in Type 1 diabetes

\begin{tabular}{ll}
\hline & References \\
\hline Islet cell (cytoplasmic) antibodies & Bottazzo et al. [11] \\
& Lendrum et al. [22] \\
& Irvine et al. [23] \\
Islet cell surface antibodies & Lernmark et al. [13] \\
& Maclaren et al. [24] \\
& Lernmark et al. [25] \\
Cytotoxic (complement mediated) & Dobersen et al. [14] \\
islet cell antibodies & Soderstrum et al. [26] \\
Immunoprecipitating islet cell antibodies & Bækkeskov et al. [15] \\
\hline
\end{tabular}

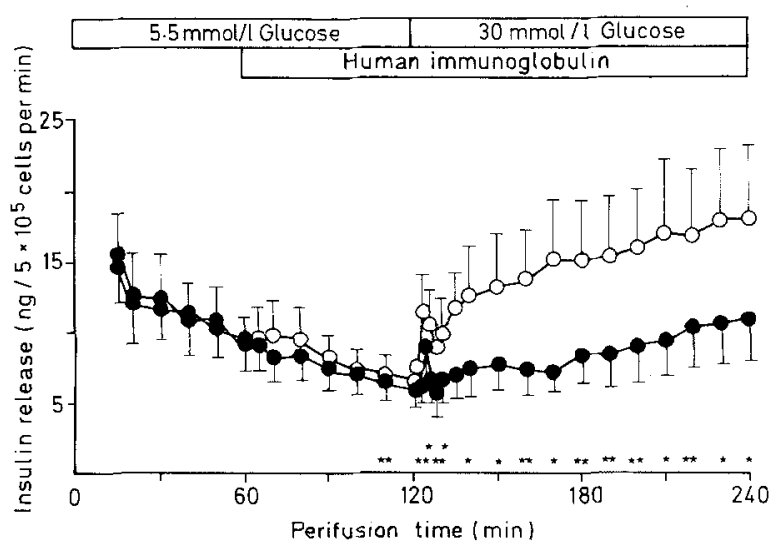

Fig. 3. Inhibition of glucose-stimuiated insulin release from columnperifused rat islet cells by human immunoglobulin prepared from the sera of Type 1 diabetic children positive for ICSA. Following a 60 -min perifusion period in the presence of D-glucose $(5 \mathrm{mmol} / 1)$ alone, the dispersed islet cells were exposed either to immunoglobulin from healthy control subjects $(\mathrm{O}-\mathrm{O})$ ) or from ICSA-positive Type 1 diabetic patients $(\longrightarrow$ ). Mean \pm SEM values for six different individuals in each group are shown. ${ }^{*} p<0.05, * * p<0.025$. [Data from 36 , reproduced with permission from the American Diabetes Association]

C-peptide levels reflected the corresponding increase in insulin requirement.

With regard to ICA, $57 \%$ of the 82 patients had antibodies at the time of diagnosis, while only $29 \%$ remained positive at 30 months. The median titres were $1: 81$ and $1: 3$, respectively, which suggest that the decrease in prevalence of ICA with increasing duration of Type 1 diabetes, is in fact due to higher levels of ICA at the time of diagnosis. Patients with a high ICA titre at onset tend to remain ICA-positive even after a prolonged period, and it was noted that the median C-peptide levels among patients with ICA persisting for 30 months were lower than corresponding values for ICAnegative patients, decreasing from $0.11 \mathrm{pmol} / \mathrm{ml}$ at 18 months to $0.09 \mathrm{pmol} / \mathrm{ml}$ at 24 months and $0.06 \mathrm{pmol} /$ $\mathrm{ml}$ at 30 months compared with $0.18(p=0.04), 0.15$ $(p=0.05)$ and $0.16(p<0.003) \mathrm{pmol} / \mathrm{ml}$, respectively. The increased rate by which fasting C-peptide levels declined in the ICA-positive patients was mirrored by the significantly increased amounts of insulin injected $(p=0.01)$ to achieve the same metabolic control as for the ICA-negative patients. Careful quantitation of ICA, therefore, may be important for the prognosis of Type 1 diabetes as it relates to insulin requirement. Although a possible cause-relationship between the decline in endogeneous insulin-production as reflected in fasting Cpeptide leveis, and diminished ICA titres cannot be defined in this study, it is possible that ICA levels somehow reflect previous $\beta$-cell destructive processes. Thus, determination of end-point titres for ICA may be a useful way to predict an increased rate of loss of endogenous $\beta$-cell function. In several recent studies (31-34), it has been documented that ICA may precede the diagnosis of Type 1 diabetes by several years. It remains to be determined whether healthy individuals with a high titre of ICA have an increased risk of developing Type 1 diabetes.

The existence of islet cell surface antibodies (ICSA) (Table 2) offers the intriguing possibility that $\beta$-cell function may be influenced by the binding of these antibodies to their antigen on the $\beta$-cell surface [13]. In initial studies attempts were made to test whether ICSA were able to affect $\beta$-cell function either directly $[35,36]$ or indirectly by their ability to mediate complement-dependent cytotoxicity [37]. Using column-perifused dispersed rat islet cells [36] and immunoglobulin prepared from sera of newly diagnosed Type 1 diabetic children and matched controls, it was found that the immunoglobulin fraction from ICSA-positive Type 1 diabetic patients inhibited glucose-stimulated insulin release (Fig. 3). These experiments suggested that ICSA in sera from Type 1 diabetic children may interfere with $\beta$-cell function in vitro, an observation which has been confirmed recently [38, 39].

Influence of ICSA on cell function in vitro does not necessarily mean that these cells are affected under conditions in vivo. Although ICSA may circulate at high levels, it does not follow that they can cross the capillary barrier to reach the target antigen on the $\beta$-cell surface. Immunoglobulin prepared from ICSA-positive plasma of Type 1 diabetic children was injected daily for 14 days into immunosuppressed mice [40]. Following the last injection, the pancreas was perfused to determine the dynamics of insulin release in response to glucose, and the pancreas was extracted for insulin determination as a measure of total pancreatic $\beta$-cell mass [41]. Although glucose-induced insulin release was diminished in these mice, the total pancreatic insulin content was unaffected, which suggests that the ICSA injected were inadequate to cause sufficient $\beta$-cell destruction to result in overt Type 1 diabetes. It is concluded that ICSA inhibit $\beta$-cell function and that longterm exposure to these antibodies may be deleterious and contribute to the development of Type 1 diabetes.

\section{What is the $\beta$-cell autoantigen?}

The possible influence of ICSA on $\beta$-cell function raises the question of which antigen(s) these antibodies are able to recognize. Since ICA are designated autoantibodies, i. e. antibodies that recognize self, the antigen 


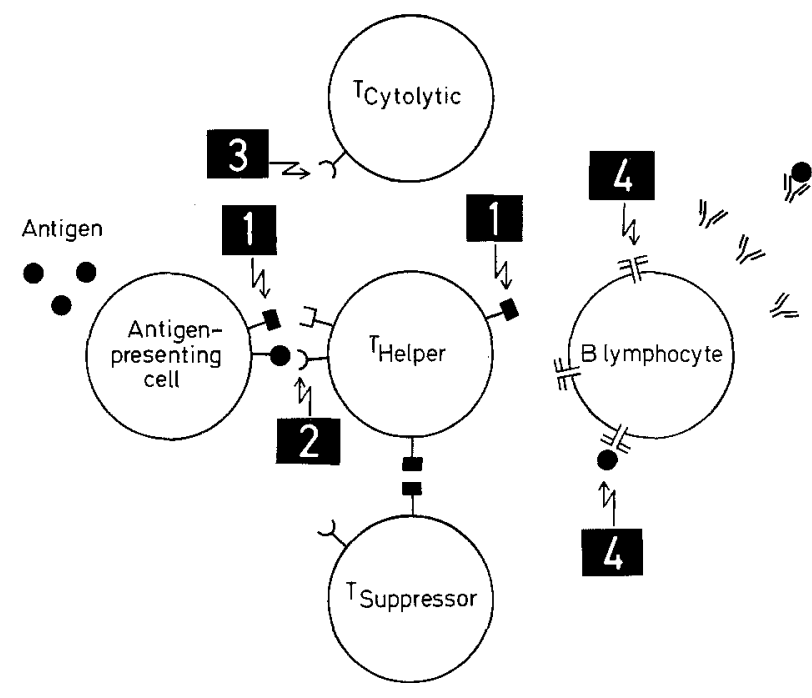

Fig.4. Pathways of cellular interactions involved when the immune system mounts a response towards a foreign antigen. Important components which may serve as targets in future attempts to control an abnormal immune response are (1) the MHC class II antigens, (2) the antigen-specific $\mathrm{T}$ lymphocyte receptor, (3) the cytolytic $\mathrm{T}$ lymphocyte receptor, or (4) the membrane-bound antibody on the B lymphocyte

detected by an autoantibody is referred to as an autoantigen. The pathway of cellular interactions involved when the immune system mounts a response towards a foreign antigen is complex and not yet explained fully (Fig.4). It is assumed that a similar pathway is also involved when an immune response occurs against an autoantigen. In brief, the antigen is presented to a T-helper lymphocyte (also called T-inducer cell), having a specific receptor for the antigen. The T-helper lymphocyte receptor is thought to be able to recognize the antigen only if it also recognizes simultaneously an MHC Class II antigen (HLA-DR antigen in man). Antigen presentation is therefore restricted, since the antigenpresenting cell must have the same Class II antigenic specificity as the T-helper lymphocyte. The activated Thelper lymphocyte can promote specifically proliferation and differentiation of cytotoxic $\mathrm{T}$ lymphocytes and/or B lymphocytes. The latter have receptors, i. e. membrane-bound antibody molecules on their cell surface. The former cells are able to recognize and kill the target cell if it is expressing the antigen on its cell surface. However, the killing is restricted since the cytolytic $\mathrm{T}$ lymphocyte will kill only if the MHC Class I antigen is shared between the T-lymphocyte and the target cell. Although the B-lymphocyte can recognize a circulating antigen, it will not proliferate and differentiate unless help, in the form of a B lymphocyte growth factor(s), is provided by the T-helper lymphocyte.

The formation of antibodies is controlled partially by the availability of antigen, but the levels of circulating antibodies may be controlled also by feed-back mechanism. This phenomenon involves the formation of antibodies which recognize the antigen-binding portion on the original antibody. This part of the antibody is the idiotype and antibodies which are formed specifically against the idiotype are referred to as anti-idiotyp- ic antibodies. Such anti-antibodies are thought to play an important role in controlling the immune response to antigens.

In order to test the hypothesis that an abnormal immune response towards the pancreatic $\beta$ cell is involved in the pathogenesis of Type 1 diabetes, it is essential to identify and characterize relevant autoantigens. In a first approach [15], pancreatic islets from human cadaver kidney donors were isolated and cultured in vitro in the presence of a radioactive amino-acid, ${ }^{35} \mathrm{~S}$-methionine. Proteins synthesized (Fig. 2) during culture will incorporate this amino-acid and become radioactive. The islets were lysed in a detergent which permits solubilization of plasma membrane-proteins, and this lysate was incubated with sera from Type 1 diabetic patients and control subjects. Immune complexes formed between autoantibody and autoantigen during incubation were first adsorbed to a Protein A-Sepharose immunosorbent, washed, and boiled in sodium dodecyl sulphate (SDS) to denature and solubilize bound antibody and antigen. The solubilized material was subjected to SDSgel electrophoresis, thus separating the proteins according to their molecular mass [15, 42]. It was found that sera from Type 1 diabetic patients specifically detected an $\mathrm{M}_{\mathrm{r}} 64000$ molecular weight component [15]. Cross-reactivity between Type 1 diabetes sera and rat pancreatic islets was also demonstrated [36]. The $M_{r} 64000$ autoantigen represents a minor islet component and it is thought to be a pancreatic $\beta$-cell specific membrane component since the presence of $M_{r} 64000$ autoantibodies coincided with that of ICSA (also $\beta$-cell specific) in the sera of Type 1 diabetic patients [15]. Current studies are aimed at the isolation and characterization of this antigen, using recent techniques of electrophoretic elution of immuneprecipitated antigens [43] and at the determination of its primary structure by microsequencing [44].

The identification and isolation of any cell-specific autoantigen would be of considerable interest since it will allow not only investigations on the mechanisms by which an autoimmune response against the autoantigen develops and is controlled in susceptible individuals, but also the development of more sensitive and specific immunoassays for autoantibodies. This is of particular importance since ICA and other immune abnormalities may be present several years before the clinical onset of Type 1 diabetes [31-34]. In one individual followed for 2 years before the diagnosis of Type 1 diabetes [35], consecutive serum samples were analyzed for their ability to immunoprecipitate the $M_{r} 64000$ autoantigen (Table 3). This analysis indicated that autoantibodies against this component also may be present before the diagnosis of Type 1 diabetes and, in fact, may precede ICA. Similar observations have been made in the spontaneously diabetic BB rat (Table 3 ) which develops insulin-dependent diabetes with many similarities to that in man [45]. In some animals which later developed insulin-dependent diabetes, both ICSA and autoantibodies against an $M_{r} 64000$ component were present even at the time of weaning $[46,47]$. 
Table 3. Presence of autoantibodies before the diagnosis of Type 1 diabetes

Studies in man [44]

\begin{tabular}{lccccc} 
& \multicolumn{6}{c}{ Months before diagnosis } \\
\cline { 2 - 5 } & 24 & 21 & 9 & 3 & 0 \\
\hline$M_{\mathrm{r}} 64000$ antibodies & + & + & + & + & + \\
ICA & - & - & - & - & -
\end{tabular}

Studies in the spontaneously diabetic BB rat [45]

Days before diagnosis

\begin{tabular}{llllll} 
& 35 & 25 & 20 & 10 & 0 \\
\hline$M_{r} 64000$ antibodies & + & + & + & + & + \\
ICSA & \pm & + & + & + & + \\
\hline
\end{tabular}

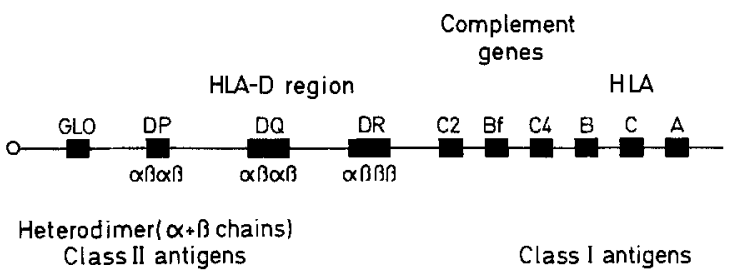

$$
\text { Class II antigens Class I antigens }
$$

Fig.5. The human MHC on the short arm of chromosome 6 with the centromere shown to the left. $\alpha$ and $\beta$ indicate the number of genes currently thought to code for these polypeptide molecules in each of the three known loci in the HLA-D region

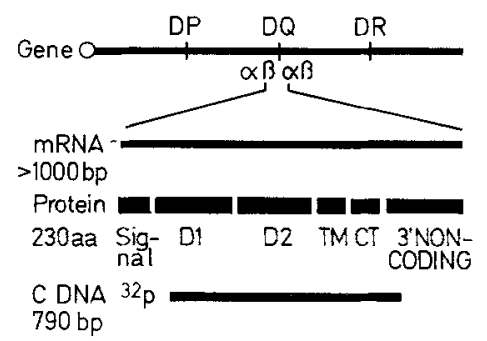

Fig.6. The HLA-DQ-chain CDNA probe used to determine restriction fragment length polymorphism in Type 1 diabetes. The cDNA probe was derived from mRNA formed by transcription of one of the HLA-DQ $\beta$-chain genes. This gene is composed of intervening sequences (introns) interrupting the coding sequences which contain the genetic information for the amino acid sequence of the signal peptide, the first domain (D1), the second domain (D2), the transmembrane region (TM), the cytoplasmic portion (CT) and the $3^{\prime}$ non-coding region

It is concluded that antibodies against the $M_{r} 64000$ antigen may be detected long before Type 1 diabetes is diagnosed and that such antibodies may be a useful marker to predict Type 1 diabetes.

\section{Genetic control of the autoimmune reaction against the pancreatic $\beta$ cell}

The autoimmune reaction against certain pancreatic $\beta$ cell antigens, often associated with the onset of Type 1 diabetes, appears not to occur in all individuals, but only in those who are HLA-DR3- and/or DR4-positive $[18,19]$. The well-documented association between Type 1 diabetes and these HLA-DR specificities is im- portant, since it may signify that genes coded for in the MHC somehow control abnormal immune reactions directed against the pancreatic $\beta$ cell. However, it is notable that although $93-98 \%$ of Type 1 diabetic patients lie within this category, the frequency of these specificities in the control population is a high as $57-58 \%$ [18, 19]. In other words, nearly half the population in a northern European country, such as the UK or Denmark, do not have the propensity to develop Type 1 diabetes. However, there remains an explanation why Type 1 diabetes, the prevalence of which is about $0.3 \%$, affects mainly the HLA-DR3- and/or DR4-positive population. One possibility is that these HLA-DR specificities are linked to a diabetogenic gene in the HLA-D region of the MHC on the short arm of chromosome 6 (Fig. 5). It is equally feasible that environmental factors may influence an abnormal process which eventually leads to sufficient disappearance of pancreatic $\beta$ cells and clinical onset of insulin-dependent diabetes. The role of viruses in the aetiology of Type 1 diabetes is much debated $[48,49]$ as is the possibility that chemical agents present in the environment might be of importance [50]. The hypothesis that environmental factors are important to the pathogenesis is supported by observations that the concordance rate for Type 1 diabetes among monozygotic twins is only 50\% or less $[51,52]$. The seasonal variation in incidence is yet another argument for an influence of environmental factor(s) $[53,54]$.

Why is it then of interest that only individuals of certain HLA-DR types develop Type 1 diabetes? The HLA-DR molecules are Class II transplantation antigens which are coded for in the HLA-D region (Fig. 5) and represent two dissimilar subunits called $\alpha$ and $\beta$ chains, being approximately $\mathrm{M}_{\mathrm{r}} 34000$ and $\mathrm{M}_{\mathrm{r}} 28000$, respectively. These heterodimeric proteins are expressed on the surface of immune competent cells and are important to the regulation of the immune response [55-57]. Recent molecular cloning of HLA-D region genes $[58,59]$ have revealed that each locus of the HLA-D region codes for one or several $\alpha$ or $\beta$ chains (Fig. 5). A cloned probe (Fig. 6) for one of the HLA-DQ $\beta$-chain genes $[61,62]$ (previously named HLA-DC but renamed at a recent meeting [60]), was used in a DNADNA hybrization analysis by Southern blotting [63]. This technique, referred to as restriction fragment length polymorphism analysis, was applied to homozygous tissue typing cells [64], HLA-DR identical control and diabetic individuals [65] and to a linkage analysis in HLA-DR typed control and diabetic families [66]. These studies showed that the polymorphism detected by the HLA-DQ $\beta$ chain, and confirmed by others [67, 68], was associated with HLA-DR and that HLA-DR identical control and Type 1 diabetic patients differ in the presence of certain restriction fragments [65]. It was concluded from these studies that the restriction fragment length polymorphism with an HLA-DQ $\beta$-chain probe is more closely associated to Type 1 diabetes than tissue type alone and that DNA probes may better de- 


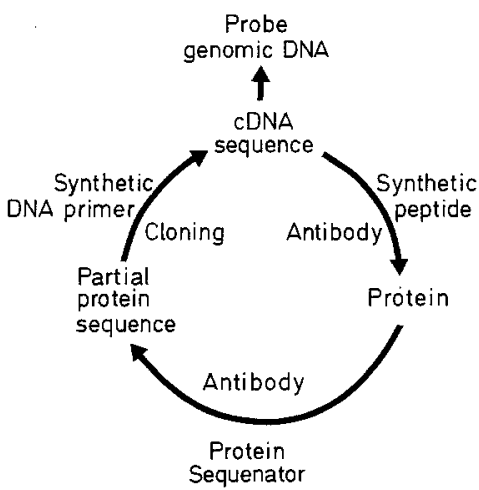

Fig. 7. A circuit of molecular biology indicating how an approach to obtain partial structural information at one level could lead to discovery of the entire structure by methods involving molecular cloning, chemical synthesis and protein chemistry

fine the risk of developing this disease. In particular, after digestion with the restriction enzyme BamHI, a fragment of about 3700 base pairs $(3.7 \mathrm{~kb})$ in size, was found rarely among Type 1 diabetic patients $[65,66]$. Instead, these patients had a BamHI $(12 \mathrm{~kb})$ fragment which was lacking in BamHI (3.7 kb) fragment-positive individuals (B. Michelsen, personal communication). Cloning of the BamHI $(3.7 \mathrm{~kb})$ fragment from the HLA-DR4-containing chromosome of an HLA-DR4/DR7-positive healthy female individual without a family history of diabetes mellitus [69] demonstrated that Type 1 diabetic patients may lack a BamHI restriction site in their genomic DNA, not in a part of a gene coding for a HLADQ $\beta$-chain, but rather in one of two possible intervening (intron) sequences. This observation suggests that Type 1 diabetes is either more closely associated to this HLA-DQ $\beta$-chain gene or that this particular genomic sequence is in close linkage to a hypothetical diabetes susceptibility gene(s).

Since intervening sequences may be important to the function of eukaryotic genes $[70,71]$, studies were initiated to determine the cell-surface expression of HLA-D region $\beta$ chains. Since these proteins are highly polymorphic, we have predicted the amino-acid sequence from cloned genes [72,73], synthesized peptides representing intramolecular sequences and raised antibodies against the peptides. These antibodies are used in an indirect immunofluorescence assay to test whether they react with the native protein. A rabbit antibody against a sequence present in the second domain of a HLA-DQ $\beta$ chain was found to recognize, not only denatured $\beta$ chains in a plasma membrane preparation, but also monocytes known to express both HLA-DQ antigens [74]. It is concluded that the generation of antibodies against synthetic short peptides may permit the detection of cell surface expressed molecules which are important to the regulation of the immune function.

\section{Future studies: possible ways of preventing diabetes}

There have been numerous attempts to intervene with the course of diseases which are associated with abber- rant immune functions. A wide variety of hormones and drugs are available to test to what extent they interfere with the appearance and the course of an autoimmune disease. In fact, in some instances, therapeutic effects of immune-modulating agents are used as a proof that the pathogenesis of a disease has an immune component. Immune-intervention, therefore, spans a broad area of medicine covering vaccination, therapy of inflammation as well as tumour and transplantation immunology. In fact, development in some of these areas has progressed very rapidly with increasing specificity of the reagents being developed. The documented precision of the immune response to recognize a foreign antigen or its ability to attack and kill a cell infected by a virus has, however, not yet been met by current approaches to influence the immune response. The major task is to be able to intervene with an immune response against a foreign antigen and only against that antigen. Dramatic examples of the opposite process, that of no precision, is total lymphoid radiation, use of cortisone or prednisone, plasmapheresis or cyclosporin A therapy. These drugs or procedures have one thing in common, namely, they inhibit or affect the entire immune system.

In Type 1 diabetes several attempts have been made to influence the course of the disease by immunetherapy [75]. Plasmapheresis, combined [76] or not [77] with steroids, prednisone $[78,79]$, interferon $[80,81]$ inosiplex [82], or methisoprinol [83] have been administered to newly diagnosed Type 1 diabetic patients without producing long-lasting insulin-independence or improvement in metabolic control. The possibility by a number of techniques, to modulate or alter the immune response to decrease the incidence of diabetes in the spontaneously diabetic BB rat [45] have further stimulated efforts to carry out early immune intervention in man. Since cyclosporin A was found to decrease the incidence of diabetes in the BB rat [84], this drug was tested in an open study in man [85]. In this study some patients were not only able to discontinue their insulin therapy but their course of endogenous insulin production showed some increase compared with other patient populations. It is recognized that cyclosporin $A$ is an effective immunosuppresive agent but it also has several side effects. A recent report indicates nephrotoxicity at therapeutic dose-levels [86]. That Type 1 diabetes is associated with powerful immune activity against the pancreatic $\beta$ cell is illustrated by the recent observations in pancreatic transplantation between identical twins who were discordant for Type 1 diabetes for more than 15 years [87]. A recurrence of Type 1 diabetes was observed in three diabetic twins receiving a pancreatic transplant without immune suppression. Not only did the function of the $\beta$ cells cease but a biopsy before and after transplantation revealed the appearance of inflammatory cells in the islets, an insulitis which was not seen before transplantation. If pancreatic transplantation is to become a possible means by which to increase the life span of Type 1 diabetic patients, it may well become necessary to administer immune suppressive therapy 
for life. In future studies, would it be possible to prevent a specific immune response directed against one particular $\beta$-cell antigen? By carefully controlling the different arms of the immune response towards an antigen, would a $\beta$-cell destructive process be influenced?

Several major approaches to influence the immune response to an antigen may be envisaged (Fig. 4). Some of them have been attempted already in other autoimmune disorders, such as experimental allergic encephalitis [88, 89], acetycholine receptor-induced myasthenia gravis $[90,91]$ or in thyroiditis [92]. Molecular cloning of the genes for antigen(s), antibodies and $T$ lymphocyte receptors, as well as MHC Class I and II antigens, are important for the analysis of those components which are central to the development of an immune response to an antigen. The structure of these components, which may form the basis on which to obtain the necessary reagents, might be obtained by a number of methods and strategies (Fig.7), all of which are available and are being utilized in a wide variety of systems [93]. Once any of these components have been identified, for example, by antibodies specifically raised against these proteins or parts of them, it should become possible to test whether any such reagent would influence the immune response (Fig.4). A targeted approach, for example, would be: (1) to raise an antibody which is directed against a specific Class II antigen molecule controlling the immune presentation mechanism. Unless such a reagent would remove only those cells which are involved in antigen presentation of pancreatic $\beta$-cell specific antigen, a complete inhibition of other important immune functions would be induced as well. (2) Another antibody of interest would be that directed against the T-cell receptor for a pancreatic $\beta$-cell specific antigen. Such an antibody may be highly specific and remove the T-lymphocyte from the circulation, thereby making an immune response towards the antigen impossible. (3) A third reagent would be an antibody to the receptor on a cytolytic $T$ lymphocyte which is able to recognize the pancreatic $\beta$ cell. Such an antibody would be ideal to influence the cellular immune killing of pancreatic B cells. (4) A fourth approach would be a specific reagent against the B-lymphocyte receptor, i.e. the antibody molecule expressed on the cell surface. This reagent could be either the antigen itself, or the antigen coupled to a toxin [92], which by being internalized would be able to kill the B-lymphocyte. One could also envisage the preparation of antibodies against the antigen-binding part of the antibody molecule. Such anti-idiotypic antibodies would be able also to bind to the T-lymphocyte receptor and influence the viability of both the B- and T-lymphocytes. Once these reagents have become available it will be possible to test the hypothesis that presentation of an autoantigen to the immune system is associated either with the development of Type 1 diabetes in susceptible individuals or with progression of the disease after diagnosis. Recent developments in molecular biology, which have opened up new avenues, will now make it possible to study Type 1 diabetes in a way that could hardly be envisaged just a few years ago.

Acknowledgement. Throughout 17 years of diabetes research I have been most fortunate to work and interact with many scientists and students who, by their own example, knowledge and skills have made research and science most worthwhile and rewarding. I am indebted also to the many technicians and other laboratory personnel for their expert assistance and support. My introduction to the laboratory and stimulus to do diabetes research was in Umeă, Sweden, and I owe a great deal to B. Hellman for his interest and support. I am greatful also to I.-B.Täljedal, L.-A. Idahl, J.Sehlin and G.Bloom for several years of training and collaboration as well as to H. Coore who provided my spark plug into science in 1967. A further stimulus to stay in the laboratory came when I joined D. F. Steiner in Chicago, and I remain indepted to Don for the exciting and stimulating years in Chicago and for his continued support and friendship. I am also grateful to A. Rubenstein and $\mathrm{H}$. Tager, together with my collaborators including D. Nielsen, Z. Freedman, T.Kanatsuna, A.Huen, K. Soderstrum, C. Patzelt and H.Zühlke. The past 5 years as the Hagedorn Research Laboratory have been particiularly exciting. The companionship of B. Hansen has been most fruitful and productive, as has the joint venture with Steno Memorial Hospital physicians, C. Binder, T. Deckert and J. Nerup. I am truly indebted to and proud to have collaborated with present and past research staff, visiting scientists and students at the Hagedorn Research Laboratory, in particular S. Baekkeskov, N. Billestrup, G. Contreas, V. Bonnevie-Nielsen, T. Deufel, T. Dyrberg, I.Gerling, W. Kastern, C. Knutsson, H.Kofod, S. Li, S.Linde, P. Mackay, O.Madsen, B. Marner, J.Martin, B. Michelsen, J. Høiriis Nielsen, O. Nielsen, D. Owerbach, G. Papadopoulos, A. Rabinovitch, J.Schøller, I. Sørensen, M. Steffes, A. Svenningsen, J.Scott, H. Vissing and B. Welinder. The support from P.A. Peterson and collaboration with B. Hägglöf and J. Ludvigsson are also greatly appreciated as is the never failing secretarial assistance from I.Bruhn-Meder, M. Søndergård and L. Brandt-Møller. Our research has been supported by the foundation Nordisk Insulin-laboratorium, the Swedish Medical Research Council, the Juvenile Diabetes Foundation and the National Institutes of Health (grants AM 26190 and 33268).

\section{References}

1. Mering J von, Minkowski O (1889) Diabetes mellitus nach Pankreasextirpation. Arch Exp Pathol Pharmakol 26:371-387

2. Minkowski O (1893) Untersuchungen über den Diabetes mellitus nach Extirpation des Pankreas. Arch Exp Pathol Pharmakol 31: 85-189

3. Gepts W (1965) Pathologic anatomy of the pancreas in juvenile diabetes mellitus. Diabetes 14: 619-633

4. Rahier J, Goebbels, Henquin JC (1983) Cellular composition of the human diabetic pancreas. Diabetologia $24: 366-371$

5. Foulis AK, Stewart JA (1984) The pancreas in recent-onset Type 1 (insulin-dependent) diabetes mellitus: insulin content of islets, insulitis and associated changes in the exocrine acinar tissue. Diabetologia 26: $456-461$

6. Nerup J, Andersen OO, Bendixen G, Egeberg J, Poulsen JE (1971) Antipancreatic cellular hypersensitivity in diabetes mellitus. Diabetes 20: 424-427

7. Mascart-Lemone F, Delespesse G, Dorchy H, Lemiere B, Servais $G$ (1982) Characterizartion of immunoregulatory $T$ lymphocytes in insulin-dependent diabetic children by means of monoclonal antibodies. Clin Exp Immunol 47: 296-300

8. Jackson RA, Morris MA, Haynes BF, Eisenbarth GS (1982) Increased circulating Ia-antigen-bearing $\mathrm{T}$ cells in type I diabetes mellitus. New Engl J Med 306: 785-788

9. Horita M, Suzuki H, Onodera T, Ginsberg-Fellner F, Fauci AS, Notkins AL (1982) Abnormalities of immunoregulatory T cell subsets in patients with insulin-dependent diabetes mellitus. J Immunol 129: 1426-1429

10. Papadopoulos G, Petersen J, Andersen V, Lernmark $\AA$, Marner B, Nerup J, Binder C (1984) Spontaneous in vitro immunoglobulin 
secretion at the diagnosis of insulin-dependent diabetes. Acta Endocrinol 105: 521-527

11. Bottazzo GF, Florin-Christensen A, Doniach D (1974) Islet cell antibodies in diabetes mellitus with autoimmune polyendocrine deficiencies. Lancet 2: 1279-1283

12. MacCuish AC, Jordan J, Campbell CJ, Duncan LJP, Irvine WJ (1974) Antibodies to islet-cell in insulin-dependent diabetics with coexistent autoimmune disease. Lancet 2: 1529-1533

13. Lernmark $\AA$, Freedman ZR, Hofmann C, Rubenstein AH, Steiner DF, Jackson RL; Winter RJ, Traisman HA (1978) Islet cell surface antibodies in juvenile diabetes mellitus. N Engl J Med 299: $375-380$

14. Dobersen MJ, Scharff JE, Ginsberg-Fellner F, Notkins AL (1980) Cytotoxic autoantibodies to beta-cells in the serum of patients with insulin-dependent diabetes mellitus. $N$ Engl J Med 303: 1493-1498

15. Bœkkeskov S, Nielsen JH, Marner B, Bilde T, Ludvigsson J, Lernmark $\AA$ (1982) Autoantibodies in newly diagnosed diabetic children immunoprecipitate human pancreatic islet cell proteins. Nature 298: 167-169

16. Nerup J, Binder C (1973) Thyroid, gastric and adrenal autoimmunity in diabetes mellitus. Acta Endocrinol 72: 279-286

17. MacCuish AC, Irvine WJ (1975) Autoimmunological aspects of diabetes mellitus. Clin Endocr Metab 4: 435-471

18. Platz P, Jakobsen BK, Morling M, Ryder LP, Svejgaard A, Thomsen M, Christy M, Kromann H, Benn J, Nerup J, Green A, Hauge $M$ (1981) HLA-D and DR-antigens in genetic analysis of insulindependent diabetes mellitus. Diabetologia 21: 108-115

19. Cudworth $A G$, Wolf $E$ (1982) The genetic susceptibility to Type 1 (insulin-dependent) diabetes mellitus. Clin Endocrinol Metab 11: 389-408

20. Owerbach D, Lernmark $\AA$, Platz P, Ryder LP, Rask L, Peterson PA, Ludvigsson J (1983) HLA-region $\beta$-chain DNA endonuclease fragments differ between HLA-DR identical healthy and insulindependent diabetic individuals. Nature 303: 815 -817

21. Steiner DF (1976) Insulin today. Diabetes $26: 322-340$

22. Lendrum R, Walker G, Gamble DR (1975) Islet-cell antibodies in juvenile diabetes mellitus of recent onset. Lancet 1:880-883

23. Irvine WJ, McCallum CJ, Gray RS, Campbell GJ, Duncan LJP, Farquhar JW, Vaughan H, Morris PJ (1977) Pancreatic islet cell antibodies in diabetes mellitus correlated with the duration and type of diabetes, co-existent autoimmune disease, and HLA-type. Diabetes 26: 138-147

24. MacLaren NK, Huang S-W, Fogh J (1975) Antibody to cultured human insulinoma cells in insulin-dependent diabetes. Lancet 1: 997-1000

25. Lernmark Å, Hägglöf B, Freedman ZR, Irvine WJ, Ludvigsson J, Holmgren $G$ (1981) A prospective analysis of antibodies reactive with pancreatic islet cells in insulin-dependent diabetic children. Diabetologia 20: 471-474

26. Soderstrum WK; Freedman ZR, Lernmark A (1979) Complement-dependent cytotoxic islet cell surface antibodies in insulindependent diabetes. Diabetes 28: 397 (Abstract)

27. Madsen OD, Cohen RM, Fitch FW, Rubenstein AH, Steiner DF (1983) The production and characterization of monoclonal antibodies specific for human proinsulin using a sensitive microdot assay procedure. Endocrinology 113: 2135-2144

28. Madsen OD, Larsson L-I, Lernmark §̊ (1985) Diffusion of C-peptide but not proinsulin from islets in frozen sections of human pancreas identified by monoclonal antibodies. Biomed Biochim Acta 44, I: $133-136$

29. Marner B, Lernmark Å, Nerup J, Molenaar JL, Tuk CW, Bruining GJ (1983) Analysis of islet cell antibodies on frozen sections of human pancreas. Diabetologia 25:93-96

30. Marner B, Agner T, Binder C, Mandrup-Poulsen T, Nerup J, Waldorff S (1984) Islet cell antibodies predict loss of fasting c-peptide. Diabetologia 27:307-308A

31. Gorsuch AN, Spencer KM, Lister J, McNally JM, Dean BM, Bottazzo GF, Cudworth AG (1981) The natural history of Type I (insulin-dependent) diabetes mellitus: evidence for a long prediabetic period. Lancet 2: $1363-1365$

32. Srikanta S, Gunda JO, Eisenbarth G, and Soeldner JS (1983) Islet cell antibodies and beta cell function in monozygotic triplets and twins initially discordant for type 1 diabetes mellitus. New Engl J Med 308: 322-325

33. Ginsberg-Fellner F, Dobersen MJ, Witt ME, Rayfield EJ, Rubinstein P, Notkins A (1982) HLA antigens, cytoplasmic islet cell antibodies, and carbohydrate tolerance in families of children with insulin-dependent diabetes mellitus. Diabetes 31: 292-298

34. Lernmark A, Baekkeskov S, Dyrberg T, Gerling I, Marner B (1984) Pathogenesis of Type 1 diabetes mellitus. In: Labrie F, Proulx L (eds) Endocrinology, Excerpta Medica. Elsevier, Amsterdam, pp 92-96

35. Lernmark A, Kanatsuna T, Rubenstein AH, Steiner DF (1979) Detection and possible functional influence of antibodies directed against the pancreatic islet cell surface. Adv Exp Med Biol 119: 157-163

36. Kanatsuna T, Baekkeskov S, Lernmark Å, Ludvigsson J (1983) Immunoglobulin from insulin-dependent diabetic children inhibits glucose-induced insulin release. Diabetes 32: 520-524

37. Kanatsuna T, Lernmark $\AA$, Rubenstein AH, Steiner DF (1981) Block in insulin release from column-perifused pancreatic $\beta$-cells induced by cell surface antibodies and complement. Diabetes 30 : 231-234

38. Helmke K, Brockhaus R, Seitz M, Otten H, Willems WR, Laube H, Federlin K (1984) Virus infection: islet cell antibodies and islet cell function in Type 1 diabetes mellitus. Behring Inst Mitt 75: $73-82$

39. Alden WW, Taylor KW, Bottazzo GF (1984) Effects of immunoglobulin and sera from newly diagnosed Type 1 (insulin-dependent) diabetic patients on glucose-induced insulin release in human islets of Langerhans. Diabetologia 27: 251 A

40. Svenningsen A, Dyrberg T, Gerling I, Lernmark $\AA$, MacKay P, Rabinovitch A (1983) Inhibition of insulin release after passive transfer of immunoglobulin from insulin-dependent diabetic children to mice. J Clin Endocrinol Metab 57: 1301-1304

41. Bonnevie-Nielsen V, Steffes MW, Lernmark $\AA$ (1981) A major loss in islet mass and $\beta$-cell function precedes hyperglycemia in mice given multiple low doses of streptozotocin. Diabetes 30:424-429

42. Laemmli UK (1970) Cleavage of structural proteins during the assembly of the head of bacteriophage T4. Nature 227: 680-685

43. Hunkapiller MW, Lujan E, Ostrander F, Hood LE (1983) Isolation of microgram quantities from polyacrylamide gels for amino acid sequence analysis. Method Enzymol 91:227-236

44. Hewick MR, Hunkapiller MW, Hood LE, Dreyer WJ (1981) A gas-liquid solid phase peptide and protein sequenator. J Biol Chem 256: 7990-7997

45. Marliss EB (ed) (1983) Workshop on the BB rat. Metabolism 32 (Suppl 1): 1-166

46. Baekkeskov S, Dyrberg T, Lernmark $\AA$ (1984) Autoantibodies against a $M_{r} 64000$ islet cell protein precede the onset of spontaneous diabetes. Science 224: 1348-1350

47. Dyrberg T, Poussier P, Nakhooda F, Marliss EB, Lernmark A (1984) Islet cell surface and lymphocyte antibodies often precede the spontaneous diabetes in the BB rat. Diabetologia 26:159-165

48. Notkins AL (1977) Virus-induced diabetes mellitus. Brief review. Arch Virol 54:1-17

49. Toniolo A, Onodera T (1984) Viruses and diabetes. In: Andreani D, Di Mario U, Federlin KF, Heding LG (eds) Immunology in diabetes. Kimpton Medical Publications, London, pp 71-93

50. Cahill GF, McDevitt HO (1981) Insulin-dependent diabetes mellitus: the initial lesion. N Engl J Med 304: 1454-1465

51. Barnett AH, Eff C, Leslie RDG, Pyke DA (1981) Diabetes in identical twins. Diabetologia 20: 87-93

52. Johnston C, Pyke DA, Cudworth AG, Wolf E (1983) HLA-DR typing in identical twins with insulin-dependent diabetes: difference between concordant and discordant pairs. Br Med $\mathrm{J} 286$ : 253-255

53. Adams SF (1926) The seasonal variation in the onset of acute diabetes: the age and sex factor in 1000 diabetic patients. Arch Intern Med 37: 861-864

54. Gamble DR, Taylor KW (1969) Seasonal incidence of diabetes mellitus. Br Med J 3: 631-633

55. Thomas DW, Yamashita U, Shevach EM (1977) The role of Ia antigens in $T$ cell activation. Immunol Rev 35: 97-120

56. Thorsby E, Berle E, Nousiainen H (1982) HLA-D region mole- 
cules restrict proliferative $\mathrm{T}$ cell responses to antigen. Immunol Rev 66: 39-56

57. Mawas C (ed) (1983) HLA-DR research in progress. Human Immunol 8:1-121

58. Shackelford DA, Kaufman JF, Korman AJ, Strominger JL (1982) HLA-DR antigens: structure, separation of subpopulations, gene cloning and function. Immunol Rev 66: 133-187

59. Bodmer J, Bodmer W (1984) Histocompatibility 1984. Immunol Today 5: 251-254

60. Nomenclature for factors of the HLA system (1984) Tissue Antigens 24: $73-80$

61. Wiman K, Larhammar D, Claesson L, Gustafsson K, Schenning L, Bill P, Böhme J, Denaro M, Dobberstein B, Hammerling U, Kvist S, Servenius B, Sundelin J, Peterson PA, Rask L (1982) Isolation and identification of a cDNA clone corresponding to an HLA-DR antigen $\beta$ chain. Proc Natl Acad Sci 79: 1703-1707

62. Schenning L, Larhammar D, Bill P, Wiman K, Jonsson AK, Rask L, Peterson PA (1984) Both $\alpha$ and $\beta$ chains of HLA-DC clas II histocompatibility antigens display extensive polymorphism in their aminoterminal domains. EMBO J 3: 447-452

63. Southern EM (1985) Detection of specific sequences among DNA fragments separated by gel electrophoresis. J Mol Biol 98: $503-517$

64. Owerbach D, Lernmark Å, Rask L, Peterson PA, Platz P, Svejgaard A (1983) Detection of HLA-D/DR-related DNA polymorphism in HLA-D homozygous typing cells. Proc Natl Acad Sci USA $80: 3758-3761$

65. Owerbach D, Lernmark $\AA$, Platz P, Ryder LP, Rask L, Peterson PA, Ludvigsson J (1983) HLA-D region $\beta$-chain DNA endonuclease fragments differ between HLA-DR identical healthy and insulin-dependent diabetic individuals Nature 303: 815-817

66. Owerbach D, Hägglöf B, Lernmark $\AA$, Holmgren G (1984) Susceptibility to insulin-dependent diabetes defined by restriction enzyme polymorphism of HLA-D region genomic DNA. Diabetes 33: 958-965

67. Cohen D, Cohen O, Marcadet A, Massart C, Lathrop M, Deschamps I, Hors J, Schuller E, Dausset J (1984) Class II HLADC $\beta$-chain DNA restriction fragments differentiate among HLADR2 individuals in insulin-dependent diabetes and multiple sclerosis. Proc Natl Acad Sci USA 81: 1774-1778

68. Henson V, Maclaren N, Wakeland E, Winter W, Brody B, Rotter J (1984) Insulin dependent diabetes (IDD) associated restriction fragment length polymorphisms (RFLP's) of DC- $\beta$ genes linked to HLA-DR4. Diabetes 33 (Suppl 1) 37 A

69. Michelsen B, Kastern W, Lernmark Å, Owerbach D (1985) Identification of an HLA-DC $\beta$-chain related genomic sequence associated with insulin-dependent diabetes. Biomed Biochim Acta 44: $33-36$

70. Gillies SD, Morrison SL, Oi VT, Tonegawa S (1983) A tissue-specific transcription enhancer element is located in the major intron of a rearranged immunoglobulin heavy chain gene. Cell 33: $717-728$

71. Weatherall DJ, Clegg JB (1982) Thalassemia revisited. Cell 29: 7-9

72. Lerner RA, Sutcliffe JG, Shinnick TM (1981) Antibodies to chemically synthesized peptides predicted from DNA sequences as probes of gene expression. Cell 23: 309-310

73. Niman HL, Houghten RA, Walker LE; Reisfeld RA, Wilson IA, Hogle JM, Lerner RA (1983) Generation of protein-reactive antibodies by short peptides is an event of high frequency: implications for the structural basis of immune recognition. Proc Natl Acad Sci USA 80: 4949-4953

74. Deufel T, Vissing H, Kofod H, Lernmark Å (1984) Antibodies against synthetic peptides recognize an HLA-Class II positive subpopulation of human peripheral blood cells. Modern approaches to vaccines, September 12-16. Cold Spring Harbor Laboratory, USA (Abstract)

75. Kolb H, Schernthaner G, Gries FA (eds) (1983) Diabetes and immunology: pathogenesis and immunotherapy. Curr Probl Clin Biochem 12: 10-140

76. Leslie RDG, Pyke DA (1980) Immunosuppression of acute insulin-dependent diabetes. In: Irvine W (ed) Immunology of diabetes. Teviot Edinburgh, pp 375-137
77. Ludvigsson J, Heding L, Liedén G, Marner B, Lernmark A (1983) Plasmapheresis in the initial treatment of insulin-dependent diabetes mellitus in children. Br Med J 286: 176-178

78. Elliott RB, Crossley JR, Berryman CC, James AG (1981) Partial preservation of pancreatic $\beta$-cell function in children with diabetes. Lancet 2,1-4

79. Ludvigsson J (1982) Prednisolone in the initial treatment of insulin-dependent diabetes mellitus in children. Acta Endocrinol (Cph) Suppl 247: 43 (Abstract)

80. Koivisto VA, Aro A, Cantell K, Haataja M, Huttunen J, Karonen S-L, Mustajoki P, Pelkonen R, Seppälä P (1984) Remissions in newly diagnosed Type 1 (insulin-dependent) diabetes: influence of interferon as an adjunct to insulin therapy. Diabetologia 27: 193-197

81. Rand KH, Rosenbloom AL, Maclaren NK, Silverstein JH, Richley WJ, Butterworth BE, Yoon JW, Rubenstein AH, Merigan TC (1981) Human leucocyte interferon treatment of two children with insulin-dependent diabetes. Diabetologia 21:116-119

82. Lander T, Standl E, Mehnert H, Bertrams B, Greulich B, Kolb H, Gries FA, Rieber EP, Riethmüller G, Albert ED (1983) Humoral and cellular immunological events in Type 1 (insulin-dependent) diabetes of recent onset: immune modulatory effects of inosiplex. Diabetologia 25: 174 (Abstract)

83. Giodano C, Galluzzo A, Burgio A, Montagna G, Pantò F, Donatelli M, Bompiani GD (1984) Immunotherapy in the early phases of Type 1 (insulin-dependent) diabetes: immunological and metabolic studies. Diabetologia 27: 279A

84. Laupacis A, Gardell C, Dutre J, Stiller CR, Keown P, Wallace AC, Thibert $\mathrm{P}$ (1983) Cyclosporin prevents diabetes in BB Wistar rats. Lancet $1: 10-11$

85. Stiller CR, Dupré J, Gent M, Jenner MR, Keown PA, Laupacis A, Martell R, Rodger NW, Graffenried Bv, Wolfe BJJ (1984) Effects of cyclosporin immunosuppression in insulin-dependent diabetes mellitus of recent onset. Science 223: 1362-1367

86. Klintmalm G, Bohman SO, Sundelin B, Wilczek H (1984) Interstitial fibrosis in renal allografts after 12 to 46 months of cyclosporin treatment: beneficial effect of low doses in early post-transplantation period. Lancet 2: 950-954

87. Sutherland DER, Goetz FC, Najarian JS (1984) Recent experience with 89 pancreas transplants at a single institution. Diabetologia 27: 149-153

88. Steinman L, Rosenbaum JT, Sriram S, McDevitt HO (1981) In vivo effects of antibodies to immune response gene products: prevention of experimental allergic encephalitis. Proc Natl Acad Sci USA 78: $7111-7114$

89. Sriram S, Schwartz G, Steinman L (1983) Administration of myelin basic protein-coupled spleen cells prevents experimental allergic encephalitis. Cell Immunol 75:378-382

90. Waldor MK, Sriram S, McDevitt HO, Steinman L (1983) In vivo therapy with monoclonal anti-Ia antibody suppresses immune responses to acetylcholine receptor. Proc Natl Acad Sci USA 80: 2713-2717

91. Hohlfeld R, Toyka KV, Heininger K, Grosse-Wilde H, Kalies I (1984) Autoimmune human T lymphocytes specific for acetylcholine receptor. Nature 310: 244-246

92. Rennie P, McGregor AM, Wright J, Weetman AP, Hall R (1983) An immunotoxin of a ricin chain conjugated to thyroglobulin selectively suppresses the antithyroglobulin autoantibody response. Lancet 1: $1338-1340$

93. Hunkapiller M, Kent S, Caruthers M, Dryer W, Firca J, Giffin C, Horvath S, Hunkapiller T, Tempst P, Hood L (1984) A microchemical facility for the analysis and synthesis of genes and proteins. Nature 310: 105-111

\section{Dr. Åke Lernmark}

Hagedorn Research Laboratory

Niels Steensensvej 6

DK-2820 Gentofte

Denmark 